\title{
Ceremonia, fiesta y poder durante los reinados de Juan II y Enrique IV de Castilla: el arte textil como síntoma de prestigio, a la luz de las Crónicas
}

\author{
Sila OREJA ANDRÉS \\ Universidad Complutense de Madrid \\ Departamento de Historia del Arte I (Medieval) \\ iduna_sila@hotmail.com
}

\section{RESUMEN}

Este artículo plantea el modo en que las fuentes cronísticas nos ayudan a dilucidar la relevancia del tejido de ornamentación en los actos ceremoniales y festivos de índole cívica, como símbolo de ostentación, indisolublemente ligado a los resortes de autolegitimación y propaganda de la monarquía y la nobleza castellanas durante los reinados de Juan II y Enrique IV. Para ello, repasaremos las circunstancias políticas y sociales que obligaron a estos dos estamentos a reforzar su imagen pública. Asimismo, analizaremos la notoriedad que alcanzaron sus fiestas y ceremonias en el espacio urbano, para, finalmente, reconocer la presencia del textil como elemento de boato en este tipo de episodios.

Palabras clave: Juan II; Enrique IV; tejido de ornamentación; fiesta y ceremonia; propaganda y legitimación.

\section{Ceremony, feast and power during the reigns of Juan II and Enrique IV of Castile: textile art as a sign of prestige, in the light of Chronicles}

\begin{abstract}
This paper deals with the importance of chronicles in the process of elucidating the relevance of ornamental textiles in ceremonial and festive acts of civic nature. Moreover, in these cases we can appreciate that ornamental textiles turned into a symbol of ostentation related to the self-legitimation and propaganda mechanisms of Castilian monarchy and nobility right through the reigns of Juan II and Enrique IV. In order to achieve this aim, we will review the political and social circumstances that forced these two estates to strengthen their public image. On top of that, we are going to analyse the notoriety attained by their feast and ceremonies in the urban area, as well as to identify the presence of textile as an element of pageantry in this sort of episodes.
\end{abstract}

Key words: Juan II; Enrique IV; ornamental textile; feast and ceremony; propaganda and legitimation. 
Este trabajo ${ }^{1}$ pretende el análisis del textil desde una perspectiva poco estudiada, su relevancia social durante el último siglo del medievo castellano. Pese a que el arte del tejido ha sido reconocido por muchos especialistas como recurso frecuente de ostentación pública, apenas se ha mostrado interés por valorar monográficamente su papel en los sistemas de legitimación y propaganda regia y nobiliaria a lo largo de los reinados de Juan II y Enrique IV.

\section{LAS NECESIDADES LEGITIMADORAS: LA PROPAGANDA REGIA Y NOBILIARIA}

Todo orden dirigente aparece íntimamente ligado a unos resortes de representación simbólica, garantes de una imagen de autoridad encaminada al fortalecimiento de su posición privilegiada, sin embargo, la convulsión social y política que azotó a la Castilla del siglo XV, favoreció además el enraizamiento de otro tipo de fórmulas de autolegitimación y propaganda ${ }^{2}$ por parte de la Monarquía Trastámara de Juan II y Enrique IV y su estrato noble.

Las circunstancias particulares que justifican esta necesidad propagandística en la política de estos dos soberanos coinciden, asimismo, con una tendencia general de transformación política en Occidente. Esta se basa, principalmente, en la existencia de unos poderes regios que reivindican, ya desde los siglos XIII y XIV, una amplificación de su marco de intervención -justicia, legislación, finanzas, control de la Iglesia-, promoviendo una inestabilidad entre los poderes principescos o monárquicos y la sociedad política, dado el marcado deseo de los primeros de imponer tendencias centralizadoras absolutistas frente a las fuerzas oligárquicas. Los medios propagandísticos, en este contexto, no sólo adquieren una dimensión de reivindicación efectiva

\footnotetext{
1 Este artículo recoge algunas de las conclusiones de mi Trabajo de Investigación Tutelada para la obtención del título oficial de Máster, defendido en diciembre de 2010 en la Universidad de Granada, bajo la dirección de la Dra. Dña. Elena Díez Jorge y con el título El arte textil en Castilla como signo de poder y prestigio, a través de las fuentes literarias: 1406-1474. Asimismo, se enmarca dentro de la colaboración científica para el proyecto de investigación nacional Caracterización de las producciones textiles de la tardoantigüedad y la Edad Media temprana: tejidos coptos, sasánidas, bizantinos e hispanomusulmanes en las colecciones públicas españolas (HAR2008-04161), a cuya investigadora principal, Laura Rodríguez Peinado, agradezco su apoyo y consejos.

2 Hemos de matizar el término de propaganda, ya que en la Edad Media no existió nada conocido como tal, siendo obviamente un concepto moderno, pero sí podemos analizar el hecho histórico desde la experiencia actual que nos confiere una expresión en la cual se encuadra a la perfección la forma de actuación de la época. JACQUES, Ellul, Historia de la propaganda, Caracas, Monte Ávila Editores, 1970, p. 37. En un intento muy acertado de hacer historia tal y como esta debió de ser, Carrasco Machado nos propone ciertos vocablos extraídos de los textos contemporáneos que podrían venir a sustituir la idea de propaganda actual en la época, tales como opinión, fama, publicar o divulgar y colorar, e igualmente, trabaja en torno a la idea de la intencionalidad propagandística en la Edad Media, sosteniendo una plena consciencia en la defensa de sus pretensiones estratégicas por parte de los políticos, a la luz de los estudios de sociología y antropología política. CARRASCO MACHADO, Ana Isabel, "Aproximación al problema de la consciencia propagandística en algunos escritores políticos del siglo XV”, en En la España Medieval, n² 21, 1998, pp. 229-269.
} 
del poder, sino que se alzan, además, como medio de dulcificación y apaciguamiento de algunas de estas tensiones ${ }^{3}$.

No obstante, para los reinados que ahora nos interesan, la coyuntura sociopolítica nos revela otro tipo de causas particulares que enmarañan aún más este contexto generalizado de crisis de legitimidad política, entendiendo el término crisis no necesariamente en un sentido negativo, sino simplemente como sinónimo de cambio político.

En primer lugar, el particular origen político de la dinastía Trastámara, presente en Castilla desde 1369, con el acceso al trono de Enrique II y como consecuencia de una guerra civil, amplía este contexto de crisis del que veníamos hablando, incrementándose la necesidad de un esfuerzo propagandístico.

En segundo lugar, no se pueden obviar las incoherencias circunstanciales entre el proyecto político de la Monarquía y los intereses de las distintas fuerzas políticas, detectándose en la primera una notoria necesidad de hacer prevalecer el concepto de poderío real absoluto sobre todos los estratos sociales, en especial para la alta nobleza y el clero, que podían ver esta iniciativa como un peligro para sus propios privilegios. Esta cláusula cancilleresca, "de mi poderío real absoluto", explicita las pretensiones regias de situarse por encima de cualquier tipo de limitación legal, alzándose como rey legislador, y recurriendo a expresiones complementarias como las de "cierta ciencia y motu propio" para justificar una decisión real susceptible de ser contraria a alguna norma vigente ${ }^{4}$.

En tercer lugar, ha de ser sopesado el capital protagonismo desempeñado por los diversos conflictos bélicos que se van planteando y que se izan como potenciadores de la actividad propagandística, y a su vez, pugnas cada vez más mediatizadas por el poder apologético. Por último, la necesidad de asegurar la continuidad dinástica alcanzó, con el caso de Enrique IV y La Beltraneja, un grado superlativo en lo que a la necesidad de una sólida estrategia de propaganda se refiere.

En definitiva, este tipo de pauta de actuación, dirigida a crear una imagen todopoderosa y atemporal de la autoridad regia ${ }^{5}$, se traduce en un predominio de imágenes del poder real caracterizadas por un despojamiento de todos los defectos propios del ser humano, para convertirla en idea perfecta, estereotipada e inolvidable. De cara a

3 Hasta el momento, el estudio más completo y, desde mi punto de vista, acertado a propósito del carácter propagandístico de la Monarquía en el periodo que aquí nos ocupa, es el capítulo dedicado a la realeza de José Manuel Nieto, del cual extraigo la mayor parte de ideas en este apartado vertidas. NIETO SORIA, José Manuel, "La Realeza", en NIETO SORIA, José Manuel (dir.), Orígenes de la Monarquía hispánica: propaganda y legitimación (ca. 1400-1520), Madrid, Dykinson, 1999, pp. 25-62.

4 NIETO SORIA, José Manuel, "La nobleza y el «poderío real absoluto» en la Castilla del siglo XV", en Cahiers de linguistique et de civilisation hispaniques médiévales, $\mathrm{n}^{\circ}$ 25, 2002, p. 238. Para una panorámica más completa de este asunto, véase un artículo previo de este mismo autor: NIETO SORIA, José Manuel, "El poderío real absoluto de Olmedo (1445) a Ocaña (1469): La Monarquía como conflicto”, en En la España medieval, $\mathrm{n}^{\circ} 21,1998$, pp. 159-228.

5 MARAVALL, José Antonio, "El concepto de Monarquía en la Edad Media española", en MARAVALL, José Antonio, Estudios de historia del pensamiento español. Serie primera: Edad Media, Madrid, Centro de estudios políticos y constitucionales, 1999, pp. 57-77, artículo publicado por primera vez en Estudios dedicados a Menéndez Pidal, tomo V, Madrid: Consejo Superior de Investigaciones Científicas, Patronato Marcelino Menéndez y Pelayo, 1954. 
los súbditos, los hechos que realice este monarca supondrán la idea que de él como individuo capten, mientras que la imagen estereotipada le da la idea genérica que va a poseer de todos los monarcas que conozca a lo largo de su vida, tratándose, entonces, de algo perdurable, poco perceptible a transformaciones ${ }^{6}$.

Por su parte, respecto a la nobleza, lo complejo de su posición social, así como una preeminencia cada vez mayor en las estructuras de poder, serán harto motivo para poner en práctica todo tipo de maniobras dirigidas a una defensa de su condición ${ }^{7}$ :

Primero, los privilegios y el poder ejercido por los nobles sobre los estratos inferiores se sustentan sobre un principio de desigualdad social que la nobleza había de hacer creer en todos los peldaños sociales, a través de estrategias de persuasión, fundamentadas en argumentos legitimadores y resortes propagandísticos ${ }^{8}$.

Segundo, los profundos conflictos políticos en los que la nobleza se vio constantemente inmersa en este periodo, producidos, entre otras cosas, por la frecuente oposición al poder regio, obliga a este estamento a desarrollar un discurso nobiliario encaminado a justificar ciertas actuaciones de rebeldía ante la autoridad, al tiempo que una retórica propagandística para atraer a su causa a otros sectores de la aristocracia y de la oligarquía urbana ${ }^{9}$.

\footnotetext{
6 NIETO SORIA, José Manuel, Fundamentos ideológicos del poder real en Castilla (siglos XIII-XVI), Madrid, Universidad Complutense, 1988, pp. 36-37.

7 Los profundos cambios que la clase noble experimentó en las postrimerías de la Edad Media, así como la compleja heterogeneidad del grupo, han sido causa de un amplio interés por parte de los especialistas, siendo el siglo XV castellano notoriamente profuso en lo que al estudio de la nobleza concierne, muy por encima, incluso, de la propia Monarquía de Juan II y Enrique IV. Sin embargo, las investigaciones no cesan, y los expertos en la materia ponen de relieve la necesidad de profundizar en ciertos aspectos aún no del todo claros, y de renovar las perspectivas de análisis. Así, Quintanilla Raso nos proporciona una revisión bastante exhaustiva del estado de la cuestión de la nobleza bajomedieval en Castilla, hasta finales de los años noventa del siglo XX, en tres publicaciones muy acertadas: "Historiografía de una elite de poder: la nobleza castellana bajomedieval", en Hispania: Revista española de historia, nº 175, 1990 (Ejemplar dedicado a: 50 años de Historiografía española y americanista, I), pp. 719-736, "El protagonismo nobiliario en la Castilla bajomedieval: una revisión historiográfica", en Medievalismo: Boletín de la Sociedad Española de Estudios Medievales, $\mathrm{n}^{\circ}$ 7, 1997, pp. 187-234 y "La renovación nobiliaria en la Castilla bajomedieval: entre el debate y la propuesta”, en VI Congreso de Estudios Medievales. La nobleza peninsular en la Edad Media. León, 1997. Madrid: Fundación Sánchez Albornoz, 1999, pp. 255-296.

8 Uno de los estudios más clarificadores en torno a este problema de la legitimación nobiliaria es el que nos ofrece Quintanilla Raso en la siguiente publicación: "La nobleza", en NIETO SORIA, José Manuel (dir.), Orígenes de la Monarquía hispánica: propaganda y legitimación (ca. 1400-1520), Madrid, Dykinson, 1999, pp. 63-96.

9 BECEIRO PITA, Isabel, "Argumentos ideológicos de la oposición nobiliaria bajo los Trastámaras", en Cahiers de linguistique et de civilisation hispaniques médiévales, $\mathrm{n}^{\circ}$ 25, 2002, p. 212. En este artículo se analiza la influencia en estos discursos ideológicos de ciertos casos ejemplares y escritos procedentes del pensamiento clásico y medieval, que fueron frecuentemente citados como criterios de autoridad por los tratadistas ético-políticos de la época.
} 


\section{LA CEREMONIA Y LA FIESTA COMO SISTEMAS DE LEGITIMACIÓN Y PROPAGANDA. LA CIUDAD COMO ESCENARIO DE REPRESENTACIÓN}

La "teatralización generalizada de la sociedad" 10 que caracterizó al Occidente medieval, implica una transposición dramática de los hechos históricos, así como de las relaciones políticas y sociales del periodo ${ }^{11}$. Así, el enriquecimiento ceremonial y festivo durante la Edad Media por parte de la Monarquía y la nobleza, pretende mejorar la imagen pública de las clases dirigentes, a través de este resorte propagandístico.

Para empezar, hemos de acotar el sentido de ambos términos, ya que, aunque ceremonia y fiesta caminan a la par, no designan la misma realidad. La ceremonia suele ir cargada de un profundo sentido legitimador, de una dimensión propagandística ${ }^{12}$ que, tal y como define Nieto Soria, se compone de un "conjunto de elementos solemnes que, sin ser esenciales para legitimar una pretensión política, contribuyen y, muchas veces, son necesarios para captar solidaridades que favorezcan su consecución, quedando, por tanto, al margen de los mecanismos legitimadores contemplados por la ley o establecidos por las tradiciones políticas del país, pero poseyendo un indudable relieve como recursos que pueden contribuir a aportar un respaldo significativo a una determinada aspiración política." ${ }^{13}$. Se trata de un acto eminentemente político que persigue tres objetivos básicos: mostrar una imagen global o parcial del poder real en su conjunto, o de algunos de sus rasgos más significativos; provocar una reacción de adhesión elemental, por tanto, no sujeta a una crítica razonable; y por último, provocar un efecto de consenso favorable a las pretensiones políticas de la realeza ${ }^{14}$.

Por el contrario, la fiesta es la proyección popular del hecho ceremonial, el acontecimiento ciudadano de ciertos eventos solemnes, y así, una de las acepciones contempladas por la Real Academia Española para el término fiesta es la que la define como "Regocijo dispuesto para que el pueblo se recree", ya que, efectivamente, no deja de ser un pretexto para que el pueblo aliviase por unas horas las calamidades de sus vidas cotidianas. Sin embargo, frente a esa necesidad de recreo de la masa popular, ha de resaltarse el cometido subyacente de algunas de estas celebraciones, que no es otro que el de servir de vehículo a las clases privilegiadas para hacer ostentación

10 BALANDIER, Georges, El poder en escenas: de la representación del poder al poder de la representación, Barcelona, Paidós, 1994, p. 36.

11 Balandier retoma la idea de Maquiavelo a propósito del estrecho paralelismo existente entre el arte del gobierno y el arte de la escena, al hacerse notar cómo todo sistema de poder se constituye como resorte cuyo propósito no es otro que el de producir determinados efectos, muchos de ellos comparables a las ilusiones suscitadas por la tramoya teatral. Así, nos habla del concepto de "teatrocracia", concebido previamente por el dramaturgo ruso Nicolás Evreinov, en referencia a la naturaleza teatral que se puede rastrear en todas las manifestaciones de la existencia social, y muy en especial en aquellas en las que el poder juega un papel protagonista BALANDIER, Georges, El poder en escenas: de la representación del poder al poder de la representación, Barcelona, Paidós, 1994, pp. 15-43.

12 Nieto Soria nos aclara que aunque tradicionalmente se ha distinguido entre ceremonias de tipo legitimador y las de tipo propagandístico, la realidad nos demuestra que las primeras nunca faltan de la segunda, e incluso viceversa. NIETO SORIA, José Manuel, Ceremonias de la realeza. Propaganda y legitimación en la Castilla Trastámara, Madrid, Nerea, 1993, pp. 23-4.

13 Ibid., p. 24.

14 NIETO SORIA, José Manuel (1999), op. cit., p. 48. 
de sus valores -en crisis, como el ideal caballeresco, que después estudiaremos- y su estatus social.

De este modo, habremos de distinguir entre las fiestas de carácter netamente folclórico y popular, normalmente asociadas al hecho religioso, como son el Corpus, la Navidad, o las fiestas dedicadas a los patronos nacionales y locales -aunque, por supuesto, también son pretexto para un extenso sistema festivo en las cortes reales y nobiliarias-, de las que se presentan como celebración de un hecho político concreto, tales como alzamientos, juras y coronaciones de nuevos monarcas, bodas, nacimientos y bautizos de príncipes y de hijos de personajes importantes, "entradas" reales, recepciones de embajadores, etc., y que son las que se prestan a un mayor despliegue de las posibilidades proselitistas de nobles y monarcas.

Las ceremonias suelen contar con una serie de factores determinantes para su éxito apologético, como son la topografía, el escenario de proyección del mensaje, los protagonistas, los emisores del mensaje, el público receptor, así como las palabras, los objetos o símbolos, la gestualidad, el desarrollo cronológico, etcétera. La fiesta, por su parte, incide en aspectos como el gasto, la sociabilidad y la ostentación; la capacidad de moldear la dimensión lúdica popular en las ciudades en su propio beneficio $\mathrm{y}$, en las fiestas de estatus, las propiamente nobiliarias, el gran protagonismo de la dimensión militar y bélica -justas, torneos, pasos de armas...- ${ }^{15}$.

Estas celebraciones sirven de marco perfecto para que, de una parte, los monarcas hagan alarde de su posición como máxima autoridad, y de otra, los nobles demuestren su posición preeminente en dos direcciones, hacia el rey y hacia sus vasallos.

La familia real aparece en estos eventos como auténtica protagonista, puesto que no sólo es el rey el portador de todo tipo de lujos, sino que toda la Corte armoniza con su figura, como gran coro sinfónico en el que cada miembro conforma un sonido esencial para lograr la melodía perfecta. Así, la Monarquía se alza como la más colosal imagen de riqueza y ostentación, como vehículo de expresión de una supremacía demasiado discutida en los reinados de Juan II y sobre todo Enrique IV.

La imagen de los nobles asociados al fasto y boato en este tipo de coyunturas, responde a un deseo de mostrar a todos los escalafones de la sociedad cuál es su posición, íntimamente vinculada a su rey, pero también como señor de sus vasallos, por lo que en ocasiones los excesos de este sector social llegaron a exceder la propia ostentación principesca.

Sea como fuere, lo que nos interesa en este momento respecto a la proyección pública de la vida de reyes y nobles es cómo en el siglo XV se produce un traslado del acto ceremonial y festivo de la corte a la calle, ya que, pese al predominio del marco cortesano, la celebración pública permite una promoción planificada y organizada, ofreciéndose una imagen de comunidad política armónicamente estructurada, en la que cada individuo y cada grupo tiene una posición definida, por lo que la ciudad se irá convirtiendo en escenario predilecto para la representación del poder regio y nobiliario en sus máximas pretensiones ${ }^{16}$.

15 QUINTANILLA RASO, María Concepción (1999), op. cit., p. 97.

16 Ibid., p. 49. 
La ciudad castellana bajomedieval, en determinados casos resultado de una serie de actuaciones repobladoras sobre el primitivo núcleo laberíntico de origen hispanomusulmán, nos ofrece dos elementos fundamentales en su constitución: la plaza y las calles, muchas de ellas ensanchadas y rectificadas en su trazado. Esta mejora de la estructura urbana evidencia un interés por disponer de un espacio público adecuado para el desarrollo de festejos de todo tipo, promovidos, como acabamos de ver, por las altas esferas de poder, como un medio directo de propaganda masiva. Hablamos, pues, de un espacio cívico polifuncional, en el que el uso cotidiano se torna festivo por medio de ligeras modificaciones ${ }^{17}$.

\section{LA PRESENCIA DEL TEXTIL DE ORNAMENTACIÓN A TRAVÉS DE LAS CRÓNICAS}

La evaluación del arte del tejido responde simultáneamente a dos planos de la realidad, por un lado a su valoración como objeto de valor económico intrínseco, y por otro a su trascendencia simbólica como arte suntuaria, es decir, la proyección social que su uso implicaba a los individuos de las clases más acomodadas ${ }^{18}$. Es más, en el siglo XV sabemos que los paños gozaron de una consideración mayor que las obras de pincel $^{19}$.

Por todo ello, veremos como el textil de ornamentación, -y por supuesto el textil indumentario, pero esto ya sería materia de otros muchos artículos-, se ofrece como vehículo ideal de las pretensiones ostentadoras de una Monarquía y una nobleza sometidas a un constante cuestionamiento.

En otro sentido, de entre todas las fuentes literarias bajomedievales castellanas, aquellas que muestran una mayor predilección por la descripción minuciosa de los eventos festivos y ceremoniales fueron las crónicas, definidas, además, por un intrínseco espíritu proselitista. El auge de este género durante el siglo XV evidencia el

17 Podríamos destacar entre los estudios más relevantes acerca del espacio de la ciudad como escenario de la fiesta medieval los de PALOMO FERNÁNDEZ, María Gema y SENRA GABRIEL Y GALÁN, José Luis, "La ciudad y la fiesta en la historiografía castellana de la Edad Media: escenografía lúdico-festiva", en Hispania: Revista española de historia, Vol. 54, 186 (1994), pp. 5-36, y LADERO QUESADA, Miguel Ángel, Fiestas en la cultura medieval, Barcelona, Areté, 2004.

18 Aunque, en definitiva, se trata del la misma melodía de base, puesto que la relevancia que las artes decorativas han protagonizado a lo largo de la Historia del Arte no habla sino del valor crematístico del objeto, y mucho más en una Edad Media en la que la singularidad de los materiales interesaba en mayor medida que las cualidades estéticas y técnicas de la obra. ZALAMA, Miguel Ángel, "Tapices en los tesoros de Juan II y Enrique IV de Castilla: su fortuna posterior", en PARRADO DEL OLMO, Jesús María (coord.), Estudios de historia del arte: homenaje al profesor de la Plaza Santiago, Valladolid, Secretariado de Publicaciones e Intercambio Científico, Universidad de Valladolid, 2009, p. 57.

19 Ibid., "La infructuosa venta en almoneda de las pinturas de Isabel la Católica", en Boletín del Seminario de Arte y Arqueología (Arte), tomo LXXIV, 2008, pp. 45-66, e ibid., "Primacía de los tapices entre las artes figurativas en España en los siglos XV y XVI", en CHECA CREMADES, Fernando (ed.), Los Habsburgo y el coleccionismo de tapices en el siglo XVI, Madrid, Fundación Carlos de Amberes, 2009 (en prensa). 
reconocimiento de los gobernantes hacia un nuevo concepto de memoria histórica ${ }^{20}$, como una dimensión más del ejercicio del poder regio y nobiliario.

La fijación por escrito de los trazos históricos de sus reinados permitía unas funciones de propaganda y legitimación que, aunque detectables ya desde el siglo XIII, logran sobredimensionar ya en el ocaso medieval el discurso de poder, anunciando el naciente espíritu renacentista ${ }^{21}$.

Asimismo, este tipo de literatura, ajena al relato de la cotidianidad, atiende especialmente a los eventos públicos de mayor relevancia, por lo que se abre como base ideal de conocimiento de la consideración social del textil.

Por su parte, de entre todos los acontecimientos celebrados en el espacio de la ciudad, son dos los que muestran con mayor intensidad la existencia de ornamentos textiles como elementos indefectibles del discurso estético del poder: las entradas reales y las fiestas de caballería.

Las esplendidas entradas de los miembros de la familia Real en las ciudades venían acompañadas de intensas labores de acondicionamiento de las calles, a través de las cuales se creaba un itinerario procesional, previamente limitado, y ricamente adornado con telas de todo tipo, que supondría el paso previo de lo que más tarde serían los complejos montajes renacentistas y barrocos 22 .

No obstante, el arreglo del espacio cívico no sólo tenía lugar con motivo de visitas regias, sino que la llegada de dignidades de todo tipo a las ciudades era razón más que suficiente para el engalanamiento sus calles:

"el dicho señor Condestable mandó facer en la plaça delante de su posada vna muy grand foguera de leña seca, e mandó alinpiar la calle que está a las espaldas, do suele correr la sortija, e adereçalla muy bien de muchas alhonbras e paños franceses bien ricos, e vn dosel de brocado a las espaldas, do avíe de çenar, e muy muchas antorchas e faraones por toda la calle e la plaça. ${ }^{23}$

Los tejidos solían aparecer como elementos colgantes de las fachadas, de los balcones y los tejados de las edificaciones que cerraban las calles del recorrido, e igualmente, se disponían a modo de toldos, bien cubriendo la totalidad de la calle, bien protegiendo parte de las edificaciones efímeras habilitadas en determinados puntos del desfile:

20 FERNÁNDEZ GALLARDO, Luis, "Sobre la crónica real en el siglo XV. Un nuevo manuscrito de la «Refundición del Halconero»”, en En la España medieval, n 27, 2004, pp. 285-316.

21 Para un mayor conocimiento en torno a este género, véanse BERMEJO CABRERO, José Luis, "Orígenes del oficio de cronista real", en Hispania, n 145, 1980, pp. 395-409; TATE, Robert Brian, Ensayos sobre la historiografía peninsular del siglo XV, Madrid, Gredos, 1970 e ibid., "El cronista real durante el siglo quince", en Homenaje a Pedro Sainz Rodríguez, Vol. 3, Madrid, Fundación Universitaria Española, 1986, pp. $659-668$.

22 NARBONA VIZCAÍNO, Rafael, “Cortejos ceremoniales, funciones religiosas y simbolismos políticos en las ciudades medievales", en: BARRIO BARRIO, José Antonio (coord.), Los cimientos del Estado en la Edad Media: cancillerías, notariado y privilegios reales en la construcción del Estado en la Edad Media, Alcoy, Marfil, 2004, pp. 233-248.

23 MATA CARRIAZO, Juan de (ed.), Hechos del Condestable Don Miguel Lucas de Iranzo: crónica del siglo $X V$, Madrid, Espasa-Calpe, 1940, p. 111. 
"E desde alli fasta la entrada de la çibdad, toda la tierra era llena de junçia e despadaña. E después, de la puente de Alcántara adelante, por todas las calles derechas fasta la yglesia mayor, asy del vno cabo de la calle como de otro, todas las paredes e los sobrados estauan colgados paños franceses, e muchos paramientos de sarga broslados e colorados. E ésto desde la puerta de la plaza fasta la yglesia mayor, e desde la puente fasta la puerta de la plaça estauan muchos rramos e mucha junçia. E desde la entrada de la calle de Çocodobe fasta la yglesia mayor estaua fecho vn çielo de pieças de paño blanco e verde e azul e colorado; e de tal manera era fecho el çielo, que no dava sol en todas las calles." 24

"Y aquel día, después que los dichos señores ovieron comido, y con ellos el señor obispo de Salamanca y todos los otros caualleros e gentes que cada día solían comer, caualgaron y fueron al mirador que la çibdad tiene fecho en la plaça del arraual; el qual estaua muy bien entoldado de muy buenos paños françeses, y muchos tapetes. $Y$ en el medio, do el dicho señor Condestable y la señora condesa avían de estar, estaua vn paño de rico brocado. ${ }^{25}$

En otra dirección, importante costumbre fue la de portar durante el itinerario urbano a estos dignos personajes llegados a las villas castellanas bajo palio, haciendo del material textil elemento decorativo, pero también símbolo inequívoco de supremacía social $^{26}$.

"E después que pasó la proçesión, descendió el Rey del cadahalso, e tenían los alcaldes e rregidores vn paño de oro clemesión brocado de dos lavores, muy rrico, con catorze varas muy largas en las manos, todas blancas argentadas. E por todas las varas desçendían desde el paño por cada vna vara vna flocadura a la rredonda en culebreta de oro e de seda clemesyn. E púsose el Señor Rey so el paño. ${ }^{27}$

Tal y como vemos en este fragmento extraído de la Crónica del Halconero, el recorrido bajo palio queda reservado a la dignidad monárquica -así como a los altos cargos eclesiásticos, de los cuales tenemos conocimiento a través de las múltiples narraciones cronísticas con motivo de la llegada de legados papales-, a la que se supedita la nobleza, de forma notoria mediante este tipo de signos externos de poder:

"E así llegaron a la çibdad de León, donde el dicho señor rey y la señora reyna fueron muy alegremente reçebido de todos los caualleros e escuderos e çibdadanos, $e$ doncellas y moças de aquella çibdad, con cantares y atanbores e otros muchos enstrumentos; y vn paño muy rico, con que metieron al señor rey, diólo su señoría al señor Condestable, y él fizo dél merçed a Martín de Mirones su criado" 28

24 CARrillo DE HUETE, Pedro, (ed. MATA CARRIAZO Y ARROQUIA, Juan de), Crónica del halconero de Juan II, Granada, Universidad de Granada, 2006, p. 110

25 MATA CARRIAZO, Juan de (ed.), op. cit. p. 54

26 ANDRÉS DÍAZ, Rosana de, "Las entradas reales castellanas en los siglos XIV y XV, según las crónicas de la época”, en En la España medieval, n 4, 1984 (Ejemplar dedicado a Ángel Ferrari Núñez, I), p. 50.

27 CARRILLO DE HUETE, Pedro, (ed. MATA CARRIAZO Y ARROQUIA, Juan de), op. cit. p. 110.

28 MATA CARRIAZO, Juan de (ed.), op. cit. p. 25. 
El segundo grupo de acontecimientos públicos en los que el textil adquiere una especial significación, es el de las fiestas de caballería, tales como justas, torneos o pasos de $\operatorname{armas}^{29}$. Estos eventos dieron lugar, no sólo a la presencia de numerosos séquitos ricamente ataviados, sino que propiciaron la creación de auténticas arquitecturas efímeras ${ }^{30}$.

"E fizo poner vn alfaneque en la plaça de Valladolid, con diez y ocho gradas de vien rricos paños de oro. E puso vna tela de paño de çestre colorado, e a la otra parte de la tela vn cadahalso çercado de paños franceses. E luego salió el señor Rey a la tela, él e otros doze cavalleros, él como Dios Padre, e los otros, todos con sus diademas, cada vno con su título del santo que era, e con su señal en la mano cada vno del martirio que avía pasado por Nuestro Señor Dios. E todas sus cubiertas de los cavallos de grana, e daragas bordadas, e vnos rrétolos que dezían: Ladrón ". ${ }^{31}$

En ciertas ocasiones, se sabe que estas construcciones se cargaron de fantasía, actuando como meros recursos de esplendor visual ${ }^{32}$, pero en la mayoría de casos, se trata de estructuras más modestas, como cadahalsos, alfaneques, o todo tipo de pabellones, destinados a un uso práctico, como espacios preeminentes en los que ubicar a las autoridades del torneo y a los invitados ilustres, y que, sin embargo, solían revestirse de modo suntuoso por medio de fastuosos tejidos, generalmente ricos en oro ${ }^{33}$ :

"E ende le fizo vna fiesta en esta manera. Mandóle poner dos cadahalsos en la dehesa que es entre San Bartolomé e San Lázaro, allende de la puente, e dos tiendas, vna en el vn cantón de la tela, e otra al otro cantón. E la tabla fue de vn paño colorado, e los palos en que estaua puesto este paño eran todos colorados; e cada canto de la tela vn álamo postiço, e ençima de cada álamo su pendón de las armas del condestable. E ellos eran fechos quadrados e pequeños, a la manera de Italia. E los cadahalsos onde el Rey e la Reyna estuvieron estauan muy bien guarnidos de paños franceses e de paños de oro, según que la razón lo rrequería”. ${ }^{34}$

29 De entre todas las publicaciones dedicadas a este espectáculo medieval, cabría destacar ANDRÉS DÍAZ, Rosana de, "Las fiestas de caballería en la Castilla de los Trastámara", en En la España medieval, nº 8 , 1986 (Ejemplar en memoria de Claudio Sánchez-Albornoz, I), pp. 81-108.

30 Para una revisión más detallada de la presencia de la arquitectura efímera en las fiestas bajomedievales castellanas, sirva la consulta de PALOMO FERNÁNDEZ, María Gema y SENRA GABRIEL Y GALÁN, José Luis (1994), capítulo II.3. “Arquitectura efímera y ciudad: escenografía lúdico-festiva” Op. Cit. pp. 31-36.

31 CARRILLO DE HUETE, Pedro, (ed. MATA CARRIAZO Y ARROQUIA, Juan de), op. cit. p. 24.

32 RUIZ, Teófilo F., "Fiestas, torneos y símbolos de realeza en la Castilla del siglo XV: las fiestas de Valladolid de 1428", en RUCQUOI, Adeline (coord.), Realidad e imágenes del poder: España a fines de la Edad Media (Coloquio «Génèse Médiévale de l'Espagne Moderne (1370-1516)», Madrid, noviembre 1987), Valladolid, Ámbito, 1988, pp. 249-266. Sirva como ejemplo paradigmático de este tipo de creaciones el espléndido conjunto arquitectónico preparado para el famosos "Paso de la Fuerte Ventura", en el marco de las fiestas celebradas en Valladolid en 1428, cuya minuciosa descripción de puede extraer de CARRILLO DE HUETE, Pedro, (ed. MATA CARRIAZO Y ARROQUIA, Juan de), Crónica del halconero de Juan II, Granada, Universidad de Granada, 2006, pp. 20-1.

33 SILVA MAROTO, Pilar, "El arte en España en la época del Primer Marqués de Santillana", en El marqués de Santillana, 1398-1458: los albores de la España Moderna (exposición), vol. 4, Hondarribia, Nerea, 2001, p. 187.

34 CARRILlO DE HUETE, Pedro, (ed. MATA CARRIAZO Y ARROQUIA, Juan de), op. cit. pp. 129-30 
El triunfo del textil como signo categórico de poder se explica por su carácter móvil, que permite la adecuación de cualquier espacio al lujo y suntuosidad requeridos para la Familia Real y los grandes nobles, sin necesidad de permanecer en el ámbito preeminente del palacio ${ }^{35}$ :

"Otrosí en medio de las tiendas do el honrrado cavallero Suero de Quiñones avía de passar, fizieron una sala de madera bien ordenada e fecha de verjas, en la qual de luengo avía trenta passos e de ancho avía diez passos muy bien compassados, e todas con paños françeses ricamente emparamentada e cubierta por ençima, de la qual sala fizieron dos mesas de madera a buena ordenanza... e en cabo de la honrrada sala estava un gran aparador de madera, fecho de gradas cubierto de madera e todo emparamentado de paños françeses en que pusiessen la plata, e que de allí sirviesen a todas las mesas, cerca de la qual sala corría uno de los ríos que la floresta e paso cercaba. ${ }^{36}$

Los ricos tejidos son un vehículo tan inmediato para el reconocimiento visual de la autoridad, que lo detectamos en todo acto público de relevancia, aunque éste no esté marcado ni por un carácter festivo ni ceremonial al uso. Sirva como ejemplo la muerte de don Álvaro de Luna que, condenado por el Rey, y ajusticiado "en la más absoluta de las deshonras" ${ }^{37}$, no renuncia a la dignidad de su persona, haciendo visible hasta el último momento la magnificencia que caracterizó su existencia. Así, un cadalso opulentamente engalanado constituyó el escenario de su trágica caída, tal y como nos explica el autor de su crónica:

"Estaba en la plaça mayor de Valladolid, acerca del monesterio que ya diximos de Sant Francisco, fecho un nuevo cadahalso para aquella nueva cosa, que jamás en Castilla non fue vista su semejante, que un tan grand señor muriese sentençiado a muerte por el Rey, e apregonado por su pregonero. E después que aquel tal cadahalso estovo guarnescido e adereş̧ado, como convenía para un tal fecho, e tendida en el suelo dél una rica alhonbra, el Diego López de Estúniga, aconpañado de gente armada, va por el bienaventurado Maestre a la posada donde posaba, el qual a la hora estaba fablando con su confesor, e dízenle que descienda de la cámara adonde estaba, e cavalgue en su mula, la qual estaba ensillada e aderesçada; así que él desçiende sin lo tardar, non lo desaconpañando los religiosos." ${ }^{38}$

No se puede dejar de lado la magnífica estampa conferida al conjunto festivo por los ricos paramentos textiles con los que los equinos solían aparecer ata-

35 El escenario natural e inmediato de la exhibición del poder no es otro que la Corte, y de hecho, ella misma forma parte de la propia imagen tanto de la realeza como de la nobleza, al presentarse como ambiente festivo por antonomasia.

36 RODRÍGUEZ DE LENA, Pero, (ed. LABANDEIRA FERNÁNDEZ, Amancio), El passo honroso de Suero de Quiñones, Madrid, Fundación Universitaria Española, 1977, pp. 105-6.

37 PÉREZ MONZÓN, Olga, "La imagen del poder nobiliario en Castilla. El arte y las Órdenes militares en el tardogótico", en Anuario de Estudios Medievales, n 37, 2, 2007, p. 931.

38 MATA CARRIAZO, Juan (ed.), Crónica de Don Álvaro de Luna, Madrid, Espasa-Calpe, 1940, p. 29. 
viados, multiplicando el efectismo en la aparición grandiosa de los personajes subidos a su montura.

"Lo qual se fizo con gran sonido de tronpetas e atabales e canpanas e otros muy diversos ynstrumentos, con universal alegría de todos los nobles e çibdadanos e populares que alli se fallaron, e de alli se fue a la yglesia mayor en una hacanea muy ricamente abillada, las camas de la qual llevaban los mas nobles que alli se fallaron levandole ençima un paño brocado muy ryco" 39

El relato de Rodríguez de Lena a propósito del paso de armas realizado por Suero de Quiñones, está plagado de referencias precisas respecto al embellecimiento de estos animales, que con sus espléndidas cubiertas textiles complementaban a la perfección tanto la decoración del espacio físico, como los ricos atavíos de los caballeros y los ilustres asistentes:

"Luego, alegre e muy apazible (Suero de Quiñones) cavalgó en su cavallo cubierto de unos ricos paramentos de azeituni bordado, vellud vellotado, azules, ellevava en las espaldas sobre las armas media huça italiana azul, rico brocado de aquel mismo paño de los paramentos del cavallo.

Tocadas las trompetas, vistas sus señales e puestas asaz de buenas lanças de armas, dentro en la liça junto al cadafalso de los juezes honrrados, arrimadas de las tres órdenes que desuso leístes, luego armado a punto de su tienda salió el generoso, esforzado cavallero, discreto Lope de Stúniga muy honrradamente ençima de su cavallo, todo encubertado de unos azules paramentos bordados de dorado, en figura de colores de la empresa e divisa quel capitán mayor Suero de Quiñones traía, según más largo vos antes desto es contado; e llevava a las spaldas ençima de las armas media uça azul de la misma devisa, e delante dé ivan a pie dos fermosos homes a manera de monteros, que llevavan en sus manos cada uno sus venablos e un valiente cavallo ensillado y enfrenado, con unos paramentos blancos de damasco broslados en ellos las sus armas de Stúniga, en el qual nin iva paje ninguno, e luego junto, çerca deste cavallo, ivan otros dos fermosos cavallos cubiertos de paramentos de un fermosos paño a manera de fuegos colorados e verdes e blancos, e ençima dellos dos pajes moçuelos chiquitos de edad de doze años muy poco más o menos, armados de todas armas a punto ambos en blanco, en sus cabezas llevavan en lugar de armaduras cada uno su caperuza de paño blanco e colorado. E el uno destos pajes llevava en su mano una espada desnuda sobre la çerviz del cavallo, e el otro una gruesa lança de armas..." ${ }^{40}$

\section{CONCLUSIONES}

Esta aproximación nos ha permitido deducir la relevancia de los actos festivos y ceremoniales como eventos para la difusión de un mensaje del poder regio y nobiliario, en

39 SÁNCHEZ-PARRA, María Pilar (ed.), Crónica anónima de Enrique IV de Castilla 1454-1474 (Crónica castellana), Madrid, Ed. De la Torre, 1991, p. 480.

40 RODRÍGUEZ DE LENA, Pero, (ed. LABANDEIRA FERNÁNDEZ, Amancio), op. cit. pp. 148 y 163. 
los que el textil se erige como recurso visual de una opulencia que define consustancialmente la supremacía de una clase.

Así, el arte del tejido fue vía predilecta para el engalanamiento de aquellas fiestas en las que sencillas arquitecturas efímeras -o en otros casos, magníficas arquitecturas efímeras- son revestidas con finos paños que dotan de color a espectáculos como torneos, justas o entradas reales a las ciudades. Sin embargo, no sólo hay que pensar en el textil como sistema de ocultación de estos montajes de poca calidad, sino que la presencia de ricas telas tapiza los muros de las suntuosas residencias palaciegas -que, en ocasiones, bien es cierto que presentan unos paramentos de baja calidad, pensados, precisamente, para ser ocultados por este material textil-, e igualmente, ornan el espacio sacro, aderezando todo tipo de celebraciones litúrgicas.

Respecto al uso de las fuentes, se puede extraer la perfecta validez de la literatura como medio de conocimiento de la trascendencia social del textil durante el siglo XV, ya que son minuciosas las descripciones aportadas por la cronística a propósito de los citados episodios festivos.

Por todo ello, es importante reivindicar el hilo que une la lucha de clase y el discurso ideológico escrito con el análisis del textil, en el que se trasciende lo estético para llegar a la relevancia de su contenido simbólico. 